\title{
The in vitro antimicrobial efficacy of Polish propolis and five plant extracts against selected bacteria and fungi
}

\author{
Adam Czyżewski', Marta Kierzkowska', Anna Majewska', Grażyna Młynarczyk' \\ ${ }^{1}$ Medical University of Warsaw, Chair and Department of Medical Microbiology, Warsaw, Poland \\ Czyżewski A, Kierzkowska M, Majewska A, Młynarczyk G. The in vitro antimicrobial efficacy of Polish propolis and five plant extracts against \\ selected bacteria and fungi. Og Nauk Zdr. 2019; 25(2): 107-111. doi: 10.26444/monz/109337
}

\begin{abstract}
Objectives. Recently, there has been interest in the use of natural products or well-known propolys as antimicrobial agents. The aim of this study was to evaluate the antimicrobial properties of Polish propolis and Plantago lanceolate L., Quercus cortex, Uncaria tomentosa, Sideritis scardica, Trifolium pratense L. extracts, and the antimicrobial effects of propolis with several plant extracts available in local stores.

Materials and method. The substances were tested for antimicrobial activity using disc diffusion test against 9 human pathogens: Escherichia coli, Pseudomonas aeruginosa, Staphylococcus aureus methicillin-resistant (MRSA), and sensitive to methicillin (MSSA), Staphylococcus epidermidis, Enterococcus faecalis, and clinical strains of Bacteroides fragilis, Candida albicans, Clostridium difficile.

Results. Q. cortex extracts showed the strongest antimicrobial activity. The methanolic extract was stronger than the aqueous extract and exhibited significant antimicrobial activity against S. aureus, including MRSA strain, S. epidermidis and C. difficile. Polish propolys most efficiently inhibited the growth of $S$. aureus strains. All plants extracts and propolis were ineffective against $B$. fragilis. After simultaneous administration of propolys with aqueous and methanolic extracts of $Q$. cortex and Q. cortex with $U$. tomentosa, the antifungal effect was improved.

Conclusions. 1) Propolys possess better activity against Gram-positive than Gram-negative bacteria. 2) Q. cortex coadministered with propolys and $Q$. cortex together with $U$. tomentosa extract demonstrated stronger inhibitory effects against C. albicans than individual plant extracts.
\end{abstract}

\section{Key words}

antibacterial effect, propolys, plant extract

\section{INTRODUCTION}

According to World Health Organization (WHO), antibiotic resistance is one of the biggest threats to global health today. Moreover, due to excessive use of commercial antimicrobial drugs the resistance is gradually increasing; therefore, many research groups are currently screening the biological activities of different plants and other natural sources to obtain potential antibacterial chemical substrates $[1,2]$. Although antibiotics lead among antimicrobial drugs, there is an increasing tendency to use traditional medicines. Recently, there has been an interest in the use of substances produced by insects, such as antimicrobial peptides (AMPs) [3] or the well known propolis.

Propolis has been used successfully for ages and has many spasmolytic, anticancer, anti-inflammatory, anesthetic, astringent, antiseptic, antibacterial, antimycotic antioxidant and immunomodulatory properties, and it is relatively nontoxic $[4,5,6,7]$.

Plant medicines are also used to treat infectious diseases and have a special application in dermatology [8]. The Plantago species (Plantaginaceae family) of herbs also been used in traditional treatment, mainly in skin disorders and infectious diseases. They produce a wide array of compounds (flavonoids, alkaloids, phenols and tannins) [9]. Plantago

Address for correspondence: Marta Kierzkowska, Medical University of Warsaw, Warsaw, Poland

E-mail: mkierzkowska@wum.edu.pl

Received:22 February 2019; Accepted: 10 May 2019 lanceolate has demonstrated good antimicrobial activity, particularly against some Gram-positive bacteria, e.g. oral Group A Streptococci and has had many historical uses as a wound healing remedy $[10,11]$.

Quercus cortex (Fagaceae family) extracts have been proven to have antibacterial and anti-oxidative properties. Q.robur extract demonstrated antibacterial activity against Staphylococcus aureus, Enterobacter aerogenes and Candida albicans [12]. Q. infectoria has proved to be a good potential agent against multi-drug resistant bacteria [13]. Uncaria tomentosa demonstrated strong antibacterial properties and has been widely used in folk medicine as a treatment of various disorders. It was demonstrated that it acts as a non-specific immunomodulating agent $[14,15,16]$ and had antimicrobial activity against microorganisms frequently found in infected root-filled teeth [17].

In Europe, Sideritis scardica (Lamiaceae family) is avery popular and widely advertised herb used in traditional medicine in the treatment of gastrointestinal complaints, inflammation, and rheumatic disorders [18]. There is no information about the antimicrobial properties of Trifolium pratense (Fabaceae Lindl. family), but it has been demonstrated that red clover is a rich source of isoflavonoids (formononetin, biochanin A, daidzein and genistein). Trifolium alexandrinum therefore has great potential in fighting Gram-positive bacteria [19, 20]. 


\section{OBJECTIVE}

The aim of this study was to evaluate the antimicrobial properties of Polish propolys and Plantago lanceolate L., Quercus cortex, Uncaria tomentosa, Sideritis scardica, Trifolium pretense L. extracts, and the antimicrobial effects of propolys with several herbs available in local stores.

\section{MATERIALS AND METHOD}

Materials. Propolis was collected near the Tuchola Forest in northern Poland, and its ethanolic extract (Propolis - 10\%, ethanol - 70\%, water - 20\%; PATALAS, Eko-Barc; Poland) was purchased at a local store. Dried parts of the plants: Plantago lanceolata (leaves; Zakład Zielarski Kawon-Hurt Nowak Sp. J., Polska), Quercus cortex (bark; Zakład Zielarski Kawon-Hurt Nowak Sp. J.), Uncaria tomentosa (bark; Astron, Przedsiębiorstwo Produkcyjno-Handlowe Józef Tabor, Polska; sample from Peru), Sideritis scardica (flowers and leaves; Astron, Przedsiębiorstwo Produkcyjno-Handlowe Józef Tabor; sample from Bulgaria) and Trifolium pretense (flowers; FLOS, Zakład Konfekcjonowania Ziół, Polska) were purchased at a local herbalist's shop. The names of plants and their parts used in the research are shown in Table 1.

Table 1. The names of plants and their parts used in the research

\begin{tabular}{|c|c|c|c|}
\hline Plant & Polish name & English name & part of the plant \\
\hline $\begin{array}{l}\text { Plantago } \\
\text { Lanceolate L. }\end{array}$ & $\begin{array}{l}\text { Babka } \\
\text { lancetowata }\end{array}$ & Ribwort Plantain & leaves \\
\hline Quercus cortex & Kora dębu & Oak bark & bark \\
\hline $\begin{array}{l}\text { Uncaria } \\
\text { tomentosa }\end{array}$ & Koci pazur & Vilcacora/Cat's claw & bark \\
\hline $\begin{array}{l}\text { Sideritis } \\
\text { scardica }\end{array}$ & Gojnik & $\begin{array}{l}\text { Mountain Tea/ } \\
\text { Shepherd's Tea/Iron wort }\end{array}$ & $\begin{array}{l}\text { flowers, stems, } \\
\text { leaves }\end{array}$ \\
\hline $\begin{array}{l}\text { Trifolium } \\
\text { Pretense L. }\end{array}$ & $\begin{array}{l}\text { Koniczyna } \\
\text { czerwona }\end{array}$ & Red Clover & flowers \\
\hline
\end{tabular}

Extraction. The extraction was carried at the Laboratory of Organic Nanomaterials and Biomolecules, Faculty of Chemistry, University of Warsaw, Poland. Extraction method was developed by the author based on Zhang QW et al. [21].

Parts of the plants $(50 \mathrm{~g})$ were weighted and divided into two portions. Each sample from the first group was extracted with deionized water in a round-bottom flask at $100^{\circ} \mathrm{C}$ for 30 minutes. The second group was extracted with methanol (Methanol czda-basic 99,8\%, POCH, Poland) at $65^{\circ} \mathrm{C}$ for 30 minutes. Then extracts were filtered with filter paper, evaporated to oily solutions of 1-5 $\mathrm{mL}$ using a vacuum rotary evaporator at $40^{\circ} \mathrm{C}$ and stored in darkness at $4^{\circ} \mathrm{C}$. The efficiency of the reaction depended on the extraction coefficient and the solvent used.

Microorganisms. The substances were tested for antibacterial activity using disc diffusion test against 9 human pathogens: Escherichia coli ATCC 25922, Pseudomonas aeruginosa ATCC 27853, methicillin-sensitive Staphylococcus aureus (MSSA) ATCC25923, methicillin-resistant Staphylococcus aureus (MRSA) - MR3, Staphylococcus epidermidis ATCC 35984, Enterococcus faecalis ATCC 29219 and clinical strains of Bacteroides fragilis, Candida albicans, Clostridium difficile.
Growth medium. For susceptibility testing, Müller-Hinton agar growth medium was used for aerobic bacteria, Brucella agar for B. fragilis and RPMI agar for C. albicans. As a growth medium, Schaedler agar was used for $B$. fragilis, CLO agar for C. difficile, and Sabourauda agar for C. albicans. All media were provided by bioMérieux, France.

The inoculum density was adjusted at $520 \mathrm{~nm}$ using a spectrophotometer to the turbidity of a $0.5 \mathrm{McF}$ arland standard with sterile saline (equivalent to $1,5 \times 10^{8} \mathrm{CFU} / \mathrm{mL}$ ) for aerobic bacteria taken from 24-hour single colonies and to $1 \mathrm{McF}$ arland standard with Brucella Broth (Grasso Biotech, Poland) for anaerobic bacteria and fungi taken from 48-hour colonies. The bacterial inoculum was spread evenly onto the surface of the agar using a sterile cotton swab. Antimicrobial assay. Disks were placed on the inoculated plates using sterile forceps and gently pressed to ensure contact. $10 \mu \mathrm{L}$ of each substance was placed on a disc using a sterile automatic pipette. Nifuroxazide (200 mg/mL; Gedeon Richter, Poland) and vancomycin $(5 \mu \mathrm{g} / \mathrm{mL}$; bioMérieux $)$, imipenem $(10 \mu \mathrm{g} / \mathrm{mL}$; bioMérieux) were used as positive control and distilled water and methanol were used as negative control. The growth of anaerobic bacteria was carried out in an anaerostat. Microorganisms were incubated for 24 and 48 hours at $37^{\circ} \mathrm{C}$. Next the zone of inhibition was measured. Results of the study were based on three independent experiments that were performed in triplicate. Data were expressed as mean \pm standard deviation (SD). The tests for every substance were repeated at least three times. The most antibacterial active samples were taken for synergistic activity tests.

\section{RESULTS}

Methanolic and aqueous extracts exhibited similar antibacterial activity, with small differences visible in Q. cortex and $U$. tomentosa extracts. All extracts were ineffective against $B$. fragilis and only a few showed weak activities against Gram-negative bacteria (propolys and $Q$. cortex aqueous extract). The $Q$. cortex extracts showed the strongest antimicrobial activity. The methanolic extract was stronger than the aqueous extract and exhibited significant antimicrobial activity against $S$. aureus, including MRSA strain, S. epidermidis and C. difficile, and possessed lower activity against $E$. faecalis and $P$. aeruginosa. In the study with the $U$. tomentosa extracts we observed that the aqueous extract stronger than methanolic inhibits growth of Staphylococci (S. aureus, S. epidermidis), E. faecalis and C. difficile. Polish propolys the most efficiently inhibited growth of studied $S$. aureus strains. This product was also active against other Gram-positive bacteria. The mean zone of inhibition of C. albicans was only $10 \mathrm{~mm}$. It is interesting to note that the extracts of Q. cortex and propolys had a weak effect on the inhibition of $C$. albicans but the antifungal activity was strengthened as a result of combining the $Q$. cortex with $U$. tomentosa, as well as the combination of propolys with methanolic extract of $Q$. cortex. The mean zone of inhibition $[\mathrm{mm}]$ by propolys and plant extracts against bacteria and C. albicans were presented in Table 2 . 
Table 2. Mean zone of inhibition $[\mathrm{M}]$ and standard deviation $[\mathrm{SD}]$ by propolis and plant extract against bacteria and C. albicans

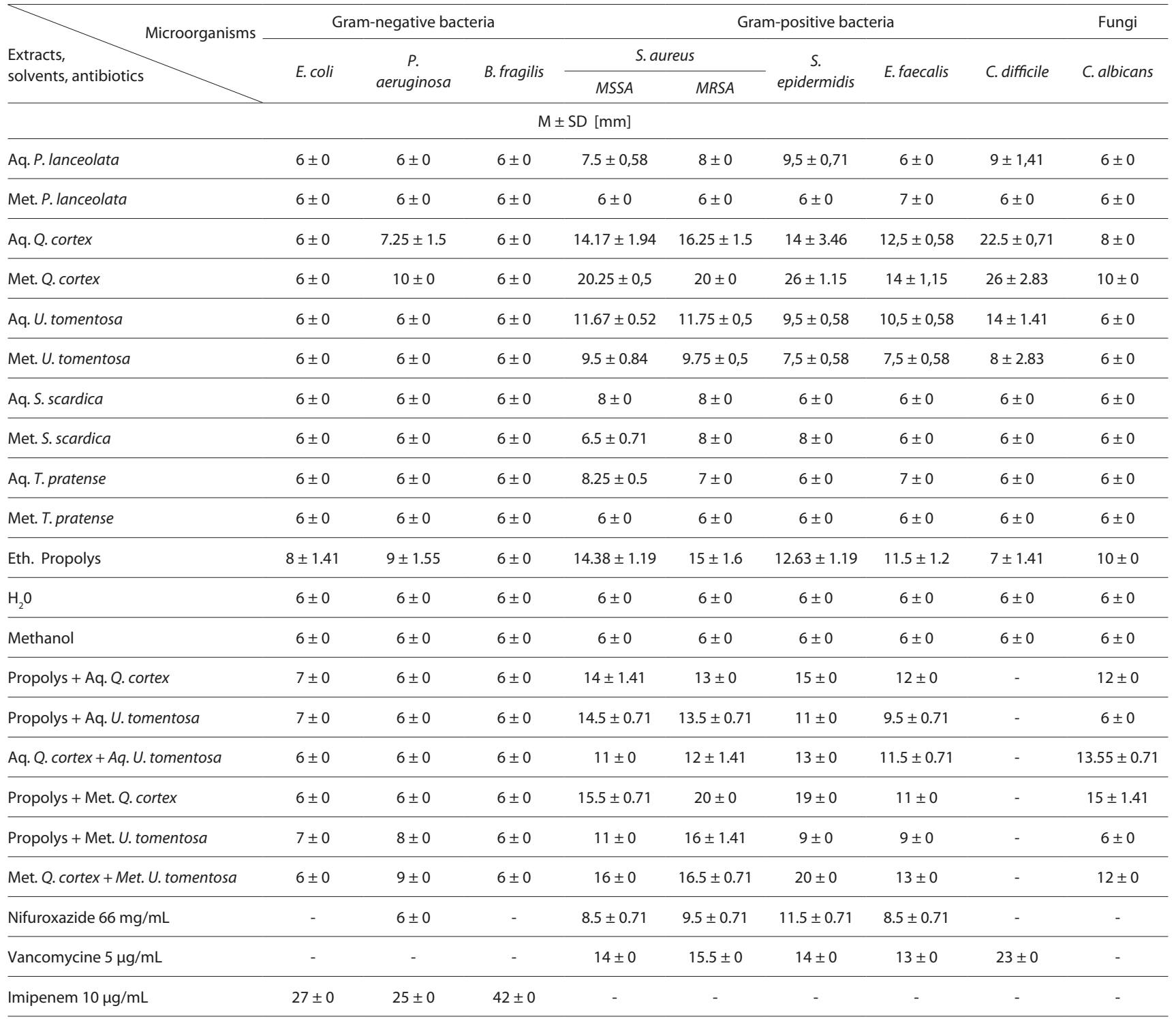

Aq. - Aqueous extract; Met. - Methanolic extract

\section{DISCUSSION}

Propolys is a name of a mixture substances collected by honeybees from parts of plants. There are records suggesting the use of propolys by ancient Egyptians, Persians, and Romans. More than 300 different compounds have been characterized so far in propolys. The most known are aliphatic acids, esters, aromatic acids, fatty acids, carbohydrates, aldehydes, amino acids, ketones, chalcones, dihydrochalcones, terpenoids, vitamins, and inorganic substances and possess greater research interest -flavonoids [22].

The antibacterial effect of propolys seems to be a representation of the synergistic activity of polyphenolics and other organic ingredients [23]. The composition of propolys depends on several factors including the origin of resinous substances from which it is produced, on bee species, season, geographical regions, additionally within the same place of growth seasonal variations in the composition of propolys has been described $[4,22,24,25]$.
In many works have been demonstrated that propolys possess activity rather against Gram-positive bacteria than Gram-negative ones $[4,6,25,23]$. The trend has also been confirmed in our study. Dziedzic A at al. demonstrrated an antibacterial effect of Polish propolys on planktonic mutans streptococci and lactobacilli collected from saliva so propolys would be promising agents for dental plaque and caries control [23]. It can also be an interesting option in the treatment of yeast infections. Gucwa et al. shown that the ethanolic extract of this natural product effectively eliminates biofilm as well as planktonic cells of Candida spp. [26].

Among the tested plant extracts there are those that inhibit the bacteria, which can have a practical significance. The Q. cortex extracts should be further evaluated for their antimicrobial activities, especially against staphylococci and C. difficile, which is naturally susceptible to only a small range of drugs and is the main reason of diarrhea identified in patients after antibiotic treatment [27]. It is well known that $Q$. cortex has been used in European folk medicine since medieval times for treatment of diarrhea, stomatitis, 
pharyngitis and skin inflammations. Recently it has been described anti-quorum sensing ability of the Q. cortex extract [28]. We demonstrated that methanolic extract of Q. cortex administered with propolys with can be a good potential candidate for fighting with C. albicans. Also U. tomentosa extracts are potential antibacterial agents. They inhibited growth of Gram-positive bacteria, the most efficiently C. difficile and $S$. aureus species.

Methanolic extract of $Q$. cortex supplemented with propolys made the diameter of growth inhibition equal $15 \pm 1.41$ in the study with C. albicans. Similarly, after combination of $Q$. cortex and $U$. tomentosa extracts we observed stronger inhibitory effects against $C$. albicans than after exposition this fungus to individual substances. According to our knowledge this combination has not been studied so far. $S$. scardica and $T$. pretense slightly inhibited growth of $S$. aureus species and were completely inactive towards the rest used in the study microorganisms. Uğur and coworkers demonstrated than the essential oils of others species of Sideritis (S. curvidens. Stapf. and S. lanata L.) had a strong effect against Gram-positive cocci (methicillin-resistant Staphylococcus aureus and Staphylococcus epidermidis) and bacilli such as Bacillus cereus and Bacillus subtilis [29]. In the other study was shown that extracts from $S$. condensate and $S$. eryhrantha var. erythrantha, used for medicinal purposes in Turkey were effective against Gram-negative bacteria. The most sensitive bacteria was $P$. aeruginosa [30]. According to the literature T. pretense possesses antioxidant activity. Extracts does not inhibit the grow of Escherichia coli (ATCC 10526), Salmonella typhimurium (ATCC 14028) and Staphylococcus aureus and other species used in our study [18]. T. pretense contains flavonoids and the phytoestrogenic effects of its extract is widely described [31].

\section{CONCLUSIONS}

1. Propolys possess better activity against Gram-positive than Gram-negative bacteria.

2. Aqueous and methanolic extracts of $Q$. cortex co-administered with propolys and aqueous extract of $Q$. cortex together with $U$. tomentosa aqueous extract demonstrated stronger inhibitory effects against $C$. albicans than individual extracts.

\section{Conflict of interest}

The authors confirm that they have no conflict of interest.

\section{REFERENCES}

1. Nam SH, Choi YR, Jang SO, Shim YS, Han GS. Antimicrobial activity of propolys on different oral bacteria. Indian J Sci Technol. 2016; 9(15): 1-4. https://doi.org/10.17485/ijst/2016/v9i15/89174

2. Karami L, Ghahtan N, Habibi H. Antibacterial Effect of Plantago ovata and Lallemantia iberica Seed Extracts against Some Bacteria. Res Mol Med (RMM). 2017; 5(3): 32-36. https://doi.org/10.29252/rmm.5.3.32

3. Kuczer M, Czarniewska E, Majewska A, Różanowska M, Rosiński G, Lisowski M. Novel analogs of alloferon: Synthesis, conformationa studies, pro-apoptotic and antiviral activity. Bioorg Chem. 2016; 66: 12-20. https://doi.org/10.1016/j.bioorg.2016.03.002

4. Martinotti S, Ranzato E. Propolys: a new frontier for wound healing? Burns Trauma. 2015; 3: 9. https://doi.org/10.1186/s41038-015-0010-z

5. Tosi B, Donini A, Romagnoli C, Brun A. Antimicrobial activity of some commercial extracts of propolys prepared with different solvents. Phytother Res. 1996; 10: 335-336.
6. Grecka K, Kuś PM, Okińczyc P, Worobo RW, Walkusz J, Szweda P. The Anti-Staphylococcal Potential of Ethanolic Polish Propolis Extracts. Molecules. 2019; 24(9): pii: E1732. https://doi.org/10.3390/ molecules24091732

7. Martinotti S, Pellavio G, Laforenza U, Ranzato E. Propolis Induces AQP3 Expression: A Possible Way of Action in Wound Healing. Molecules. 2019; 24(8): pii: E1544. https://doi.org/10.3390/molecules24081544

8. Wolski T, Najda A, Kędzia B, Wolska-Gawron K. Phytotherapy of dermatological diseases [Polska]. Post Fitoter. 2017; 18: 298-308.

9. Karima S, Sahli F, Zerroug MM. Antioxidant and antimicrobial activities of Plantago major. Int J Pharm Pharm Sc. 2015; 7(5): 58-64.

10. Ferrazzano GF, Cantile T, Roberto L, Ingenito A, Catania MR, Roscetto E i wsp. Determination of the in vitro and in vivo antimicrobial activity on salivary Streptococci and Lactobacilli and chemical characterisation of the phenolic content of a Plantago lanceolata infusion. Biomed Res Int. 2015; 2015: 286817. http://dx.doi.org/10.1155/2015/286817

11. Parus A, Grys A. Plantago lanceolata L. - medicinal properties [Polska]. Post Fitoter. 2010; 3: 162-165.

12. Andrensek S, Simonovska B, Vovk I, Fyhrquist P, Vuorela H, Vuorela P. Antimicrobial and antioxidative enrichment of oak (Quercus robur) bark by rotation planar extraction using ExtraChrom. Int J Food Microbiol. 2004; 92(2): 181-187. https://doi.org/10.1016/j.ijfoodmicro.2003.09.009

13. Wan NorAmilah WA, Masrah M, Hasmah A, Noor Izani NJ. In vitro antibacterial activity of Quercus infectoria gall extracts against multidrug resistant bacteria. Trop Biomed. 2014; 31(4): 680-688.

14. Garcia R, Cayunao C, Bocic R, Backhouse N, Delporte C, Zaldivar M i wsp. Antimicrobial activity of isopteropodine. Z Naturforsch C. 2005; 60(5-6): 385-388.

15. Ccahuana-Vasquez RA, Santos SS, Koga-Ito CY, Jorge AO. Antimicrobial activity of Uncaria tomentosa against oral human pathogens. Braz Oral Res. 2007; 21(1): 46-50.

16. Kloucek P, Polesny Z, Svobodova B, Vlkova E, Kokoska L. Antibacterial screening of some Peruvian medicinal plants used in Calleria District. J Ethnopharmacol. 2005; 99(2): 309-312. https://doi.org/10.1016/j. jep.2005.01.062

17. Herrera DR, Tay LY, Rezende EC, Kozlowski VA Jr, Santos EB. In vitro antimicrobial activity of phytotherapic Uncaria tomentosa against endodontic pathogens. J Oral Sci. 2010; 52(3): 473-476.

18. Tadic V, Bojovic D, Arsic I, Dorđević S, Aksentijevic K, Stamenić M i wsp. Chemical and antimicrobial evaluation of supercritical and conventional Sideritis scardica Griseb., Lamiaceae extracts. Molecules. 2012; 17(3): 2683-2703. https://doi.org/10.3390/molecules17032683

19. Khan AV, Ahmed QU, Shukla I, Khan AA. Antibacterial activity of leaves extracts of Trifolium alexandrinum Linn. against pathogenic bacteria causing tropical diseases. Asian Pac J Trop Biomed. 2012; 2(3):189-194. https://doi.org/10.1016/S2221-1691(12)60040-9

20. Wang SW, Chen Y, Joseph T, Hu M. Variable isoflavone content of red clover products affects intestinal disposition of biochanin A, formononetin, genistein, and daidzein. J Altern Complement Med. 2008; 14(3): 287-297. https://doi.org/10.1089/acm.2007.0617

21.Zhang QW, Lin LG, Ye WC. Techniques for extraction and isolation of natural products: a comprehensive review. Chin Med. 2018;13:20. https://doi.org/10.1186/s13020-018-0177-x

22. Zabaiou N, Fouache A, Trousson A, Baron S, Zellagui A, Lahouel M i wsp. Biological properties of propolis extracts: Something new from an ancient product. Chem Phys Lipids. 2017; 207: 214-222. https://doi. org/10.1016/j.chemphyslip.2017.04.005

23. Dziedzic A, Kubina R, Wojtyczka RD, Kabała-Dzik A, Tanasiewicz M, Morawiec T. The antibacterial effect of ethanol extract of polish propolis on mutans streptococci and lactobacilli isolated from saliva. Evid Based Complement Alternat Med. 2013; 2013: 681891. http://dx.doi. org/10.1155/2013/681891

24. Bonamigo T, Campos JF, Alfredo TM, Balestieri JB, Cardoso CA, Paredes-Gamero EJ i wsp. Antioxidant, cytotoxic, and toxic activities of propolys from two native bees in Brazil: Scaptotrigona depilis and Melipona quadrifasciata anthidioides. Oxid Med Cell Longev. 2017; 2017: 1038153. https://doi.org/10.1155/2017/1038153

25. das Neves MV, da Silva TM, Lima Ede O, da Cunha EV, Oliveira Ede J. Isoflavone formononetin from red propolys acts as a fungicide against Candida sp. Braz J Microbiol. 2016; 47(1):159-166. https://doi. org/10.1016/j.bjm.2015.11.009

26. Gucwa K, Kusznierewicz B, Milewski S, Van Dijck P, Szweda P. Antifungal Activity and Synergism with Azoles of Polish Propolis. 2018; 7(2):56. https://doi.org/10.3390/pathogens7020056

27. Brown K, Valenta K, Fisman D, Simor A, Daneman N. Hospital ward antibiotic prescribing and the risks of Clostridium difficile infection. JAMA Intern Med. 2015; 175(4): 626-633. 
28. Deryabin DG, Tolmacheva AA. Antibacterial and anti-quorum sensing molecular composition derived from Quercus cortex (Oak bark) Extract. Molecules. 2015; 20(9): 17093-17108. https://doi.org/10.3390/ molecules200917093

29. Uğur A, Varol O, Ceylan Ö. Antibacterial Activity of Sideritis curvidens. and Sideritis lanata. from Turkey. Pharmaceutical Biology. 2005; 43(1): 47-52. https://doi.org/10.1080/13880200590903354
30. Özkan G, Sagdiç O, Özcan M, Özçelik H, Ünver A. Antioxidant and antibacterial activities of Turkish endemic Sideritis extracts. Grasas y Aceites. 2005; 56(1): 16-20. https://doi.org/10.3989/gya.2005.v56.i1.129 31. Kargozar R, Azizi H, Salari R. A review of effective herbal medicines in controlling menopausal symptoms. Electronic Physician. 2017; 9(11): 5826-5833. https://doi.org/10.19082/5826

\title{
Przeciwdrobnoustrojowa skuteczność polskiego propolisu i pięciu ekstraktów roślinnych przeciwko wybranym bakteriom i grzybom in vitro
}

\begin{abstract}
I Streszczenie
Cel pracy. Ostatnio pojawiło się zainteresowanie wykorzystaniem naturalnych produktów oraz dobrze znanego propolisu jako środków przeciwdrobnoustrojowych. Celem badania była ocena właściwości przeciwdrobnoustrojowych polskiego propolisu oraz ekstraktów Plantago lanceolata L., Quercus cortex, Uncaria tomentosa, Sideritis scardica, Trifolium pratense L., a także łącznego działania propolisu i ekstraktów roślinnych względem wybranych drobnoustrojów.

Materiał i metody. Aktywność przeciwdrobnoustrojowa propolisu i ekstraktów roślinnych względem 9 drobnoustrojów chorobotwórczych wywołujących zakażenie u ludzi, jakimi są: Escherichia coli, Pseudomonas aeruginosa, Staphylococcus aureus metycylino-oporny (MRSA) i wrażliwy na metycylinę (MSSA), Staphylococcus epidermidis, Enterococcus faecalis, Bacteroides fragilis, Candida albicans i Clostridium difficile, badano metodą dyfuzyjno-krążkową.

Wyniki. Najsilniejsze działanie przeciwdrobnoustrojowe wykazuje ekstrakt z Q. cortex. Ekstrakt metylowy okazał się silniejszy niż wodny i wykazał istotne działanie przeciwdrobnoustrojowe przeciwko S. aureus, łącznie ze szczepami MRSA, a także S. epidermidis i C. difficile. Polski propolis najsilniej redukował wzrost szczepów S. aureus. Żaden z badanych ekstraktów roślinnych oraz proplis nie hamowały wzrostu B. fragilis. Skojarzenie propolisu z wodnym i metylowym ekstraktem Q. cortex oraz skojarzenie ekstraktów Q. cortex oraz U. tomentosa spowodowało silniejszy efekt przeciwgrzybiczy niż pojedyncze ekstrakty.

Wnioski. 1. Propolis posiada lepsze działanie przeciwko bakteriom Gram-dodatnim niż Gram-ujemnym. 2. Ekstrakt z Q. cortex stosowany jednocześnie z propolisem oraz Q. cortex wraz z ekstraktem z U. tomentosa wykazy wały silniejsze działanie wobec C. albicans niż poszczególne ekstrakty roślinne aplikowane pojedynczo.
\end{abstract}

\section{Słowa kluczowe}

działanie przeciwbakteryjne, propolis, ekstrakt roślinny 